\title{
Pengaruh Sosialisasi Terhadap Tax Amnesty Dengan Risiko Offshore Investment dan Kemudahan Prosedur Sebagai Pemoderasi
}

\author{
A.A Istri Syania Vihira Nanda1 \\ Fakultas Ekonomi dan Bisnis \\ Universitas Udayana, Indonesia \\ Email: syaniavihirananda@gmail.com
}

\author{
Naniek Noviari ${ }^{2}$ \\ Fakultas Ekonomi dan Bisnis \\ Universitas Udayana, Indonesia
}

\begin{abstract}
ABSTRAK
Penelitian ini ditujukan untuk mendapat bukti empiris pengaruh sosialisasi perpajakan terhadap tax amnesty juga moderasi kemudahan prosedur dan risiko offshore investment terhadap pengaruh sosialisasi perpajakan pada tax amnesty. Penelitian ini dilakukan pada Wajib Pajak yang terdaftar di Kantor Pelayanan Pajak Pratama Badung Utara dengan metode convenience sampling. Teknik analisis yang digunakan adalah regresi logistik biner dengan moderating regression analysis (MRA). Berdasarkan hasil penelitian ini menunjukkan bahwa sosialisasi perpajakan berpengaruh signifikan positif terhadap tax amnesty yang berarti semakin tinggi sosialisasi perpajakan maka semakin tinggi partisipasi tax amnesty. Interaksi kemudahan prosedur dan sosialisasi perpajakan berpengaruh signifikan positif yang berarti bahwa kemudahan prosedur mampu memperkuat hubungan sosialisasi perpajakan terhadap tax amnesty. Interaksi risiko offshore investment berpengaruh positif namun tidak signifikan terhadap tax amnesty yang berarti bahwa risiko offshore investment tidak mampu memperkuat hubungan sosialisasi perpajakan terhadap tax amnesty.
\end{abstract}

Kata Kunci: Tax Amnesty; Kemudahan Prosedur; Risiko Offshore Investmet.

\section{The Effect of Dissemination on Tax Amnesty with Offshore Investment Risk and Ease of Procedures as Moderating}

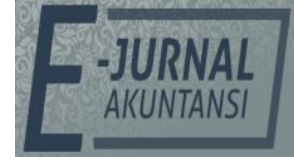

E-JA

e-Jurnal Akuntansi e-ISSN 2302-8556

Vol. 30 No. 2

Denpasar, Februari

Hal. 277-292

Artikel Masuk: 7 November 2019

Tanggal Diterima: 5 Desember 2019

This reaserch aims to obtain empirical evidence of the effect of taxation socialization on tax amnesty as well as moderation of ease of procedures and the risk of offshore investment on the effect of tax socialization on tax amnesty. This research was conducted on taxpayers registered at the North Badung Primary Tax Service Office with a convenience sampling method. The analysis technique used is binary logistic regression with moderating regression analysis (MRA). Based on the results of this study indicate that taxation socialization has a significant positive effect on tax amnesty which means the higher the taxation socialization, the higher the tax amnesty participation. The interaction between ease of procedure and taxation socialization has a significant positive effect, which means that ease of procedure is able to strengthen the relationship between taxation socialization and tax amnesty. The interaction of offshore investment risks has a positive but not significant effect on tax amnesty which means that offshore investment risks are not able to strengthen the relationship of tax socialization to tax amnesty.

Keywords: Tax Amnesty; Ease of Procedure; Offshore Investment Risk 


\section{PENDAHULUAN}

Saat ini Indonesia masih termasuk dalam negara yang memiliki tingkat penerimaan pajak yang rendah. Dirjen Pajak menjelaskan bahwa saat ini rasio penerimaan pajak (tax ratio) Indonesia saat ini berada di angka 11,5\% (Kemenkeu.go.id, 2019). Angka tax ratio Indonesia masih jauh dibawah negaranegara ASEAN lain seperti Malaysia yang memiliki tax ratio 15\%, Filipina yang memiliki tax ratio $14,5 \%$ dan Singapura yang memiliki tax ratio $13,6 \%$. Rasio penerimaan pajak Indonesia bahkan masih jauh berada di bawah standar negaranegara Organization on Economic Cooperation and Development (OECD) yang umumnya memiliki tax ratio sebesar 14\% (Kemenkeu.go.id, 2019).

Penerimaan pajak penghasilan $(\mathrm{PPh})$ orang pribadi di Indonesia secara rata-rata jauh lebih rendah dengan negara lainnya. Danny Darussalam Tax Centre (DDTC) menjelaskan bahwa PPh wajib pajak orang pribadi di luar PPh 21 dalam Pendapatan Domestik Bruto (PDB) di Indonesia pada 2016 hanya sebesar 0,5\% dan 2017 sebesar 0,7\% dari total pajak. Capaian ini jauh lebih rendah dari negara lainnya seperti Italia dan Belgia. Di Italia pendapatan pajak dari orang pribadi mencapai $16,8 \%$ sementara Belgia menerima 15,3\% pajak dari orang pribadi (Kontan.co.id, 2018)

Kontribusi wajib pajak orang pribadi dalam penerimaan pajak masih sangat rendah di Bali. Kepala Kanwil DJP Bali Goro Ekanto menyatakan bahwa kontribusi wajib pajak orang pribadi di Bali kurang lebih hanya $1 \%$ dari total penerimaan pajak. Umumnya untuk negara menuju negara modern penerimaan pajak dari wajib pajak orang pribadi setidaknya imbang atau lebih besar dari penerimaan pajak badan usaha (Balipost, 2019).

KPP Pratama Badung Utara merupakan salah satu Kantor Pelayanan Pajak di Bali yang terindikasi adanya masalah kepatuhan dari wajib pajaknya. Indikasi masalah kepatuhan ini ini dibuktikan dengan masih banyak wajib pajak di KPP Pratama Badung Utara tidak tepat waktu menyampaikan SPT tahunannya, bahkan masih ada wajib pajak yang tidak menyampaikan SPT tahunannya. Tabel penyampaian SPT tahunan wajib pajak di KPP Pratama Badung Utara disajikan sebagai berikut.

Tabel 1. Penyampaian SPT Tahunan Wajib Pajak di KPP Pratama Badung Utara Tahun 2016 sampai 2018

\begin{tabular}{llllllll}
\hline $\begin{array}{l}\text { Tahun } \\
\text { Penyampaian } \\
\text { SPT }\end{array}$ & $\begin{array}{l}\text { Jumlah } \\
\text { WP }\end{array}$ & $\begin{array}{l}\text { Tepat } \\
\text { Penyampaian }\end{array}$ & $\begin{array}{l}\text { Waktu } \\
\text { Efektif }\end{array}$ & $\begin{array}{l}\text { Terlambat } \\
\text { Menyampaikan } \\
\text { SPT }\end{array}$ & \multicolumn{2}{l}{$\begin{array}{l}\text { Tidak } \\
\text { Menyanpaikan } \\
\text { SPT }\end{array}$} \\
\cline { 2 - 9 } & $\begin{array}{l}\text { Jumlah } \\
\text { (Orang) }\end{array}$ & $\begin{array}{l}\text { Jumlah } \\
\text { (Orang) }\end{array}$ & $\%$ & $\begin{array}{l}\text { Jumlah } \\
\text { (Orang) }\end{array}$ & $\%$ & Jumlah \\
(Orang) & $\%$ \\
\hline 2016 & 47.004 & 22.404 & $47,66 \%$ & 4.810 & $10,23 \%$ & 15.838 & $33,70 \%$ \\
2017 & 50.638 & 24.235 & $47,86 \%$ & 2.487 & $4,91 \%$ & 19.321 & $38,15 \%$ \\
2018 & 55.627 & 25.932 & $46,62 \%$ & 1.190 & $2,14 \%$ & 24.077 & $43,30 \%$ \\
\hline
\end{tabular}

Sumber: Kantor Pelayanan Pajak Pratama Badung Utara, 2019

Data pada Tabel 1. menggambarkan jumlah wajib pajak orang pribadi yang terus meningkat. Namun, seiring dengan peningkatan jumlah wajib pajak, terlihat bahwa tingkat kepatuhan semakin menurun dilihat dari semakin banyak wajib pajak yang tidak menyampaikan SPT tahunannya. Di KPP Pratama Badung Utara juga masih ada wajib pajak yang terlambat menyampaikan SPT 
tahunannya meskipun jumlahnya semakin berkurang tiap tahunnya. Hal ini mengindikasikan adanya sikap tidak patuh yang dilakukan oleh wajib pajak di KPP Pratama Badung Utara.

Penerimaan pajak di KPP Pratama Badung Utara juga tidak pernah memenuhi target. Dengan penerimaan yang tidak mencapai target ini mengindikasikan adanya wajib pajak yang tidak patuh. Tabel target penerimaan pajak dan realisasinya disajikan pada Tabel 2.

Tabel 2. Rasio Penerimaan Pajak di KPP Pratama Badung Utara pada Tahun 2016-2018

\begin{tabular}{|c|c|c|c|}
\hline Tahun & Target & Realisasi & Rasio Penerimaan* \\
\hline 2016 & Rp $\quad 619.919 .595 .000,00$ & $\mathrm{Rp} \quad 491.782 .831 .240,00$ & $79 \%$ \\
\hline 2017 & Rp $586.131 .479 .000,00$ & Rp $540.969 .168 .114,00$ & $92 \%$ \\
\hline 2018 & $\operatorname{Rp} \quad 660.034 .517 .000,00$ & $\operatorname{Rp} \quad 628.143 .773 .394,00$ & $95 \%$ \\
\hline
\end{tabular}

${ }^{*}$ Rasio Penerimaan $=($ Realisasi $:$ Target $) \times 100 \%$

Sumber: Kantor Pelayanan Pajak Pratama Badung Utara, 2019

Rendahnya penerimaan pajak ini diakibatkan oleh kepatuhan wajib pajak yang dinilai masih rendah. Pengamat Perpajakan dari Danny Darussalam Tax Centre (DDTC) menyatakan, rendahnya kesadaran kesadaran wajib pajak dalam kepatuhan perpajakannya membuat pembangunan yang dilakukan pemerintah sulit tercapai (Kontan.co.id, 2018).

Untuk meningkatkan penerimaan pajak sekaligus meningkatkan kepatuhan wajib pajak maka Indonesia menerapkan Tax amnesty. Dalam Undang-Undang No. 11 tahun 2016 diatur ketentuan-ketentuan mengenai tax amnesty. Dalam pasal 1 ayat 1 disebutkan bahwa pengampunan pajak adalah penghapusan pajak yang seharusnya terutang, tidak dikenakan sanksi administrasi perpajakan dan sanksi pidana di bidang perpajakan, dengan cara mengungkap harta dan membayar uang tebusan sebagaimana diatur dalam undang-undang. Tax amnesty adalah kebijakan pemerintah dalam perpajakan yang memberikan pengampunan pajak kepada wajib pajak yang tidak patuh agar menjadi wajib pajak yang patuh (Devano \& Rahayu, 2006). Dengan adanya tax amnesty, pemerintah memberikan kompensasi perpajakan agar wajib pajak yang belum melaporkan harta kena pajaknya segera melapor saat masa tax amnesty berlangsung. Semakin banyak wajib pajak yang transparan terhadap aset yang dimilikinya maka semakin besar pula pajak yang akan didapat dikemudian hari setelah program tax amnesty berlangsung.

Berdasarkan penelitian Putra et al. (2018) pada periode sejak berlakunya tax amnesty jumlah wajib pajak terdaftar mengalami peningkatan. Peningkatan jumlah wajib pajak terdaftar dapat dikaitkan dengan peningkatan kepatuhan wajib pajak. Tax Amnesty berpengaruh positif terhadap kepatuhan wajib pajak (Rahayu, 2016). Berdasarkan penelitian sebelumnya maka dapat diartikan bahwa program tax amnesty merupakan salah satu bentuk kompensasi pajak yang dapat meningkatkan kepatuhan wajib pajak.

Tax Amnesty merupakan program yang menguntungkan baik bagi negara maupun bagi wajib pajak. Bagi negara, tax amnesty dapat meningkatkan transparansi aset dari wajib pajak dan kedepannya dapat meningkatkan penerimaan negara. Sementara bagi wajib pajak, keuntungan mengikuti tax 
amnesty adalah wajib pajak mendapat pengampunan pajak terutang, sanksi administrasi dan sanksi pidana yang belum diterbitkan, tidak dilakukan pemeriksaan pajak serta pemeriksaan bukti permulaan, dan penghapusan $\mathrm{PPh}$ Final atas pengalihan Harta berupa tanah dan/atau bangunan serta saham (Kumalasari, et al., 2017). Meskipun tax amnesty menguntungkan, masih banyak wajib pajak yang belum mengikuti program Tax Amnesty. Hal ini terbukti dengan tingkat partisipasi Wajib Pajak yang ikut tax amnesty hanya sejumlah 891.557 orang atau 4,436\% dari jumlah Wajib Pajak yang melaporkan Surat Pemberitahuan (SPT) atau 2,276\% dari jumlah Wajib Pajak yang memiliki Nomor Pokok Wajib Pajak (Tempo.co, 2017). Pada agustus 2019, Mentri Keuangan Sri Mulyani memberi sinyal akan diadakannya tax amnesty jilid II karena program tax amnesty sebelumnya masih belum banyak diikuti oleh Wajib Pajak.

Untuk memperkenalkan program tax amnesty pada masyarakat maka perlu digencarkan sosialisasi. Sosialisasi pajak yang intensif dapat meningkatkan pengetahuan calon wajib pajak mengenai semua hal yang berkaitan dengan perpajakan (Jannah \& Basuki, 2016). Jika wajib pajak calon peserta tax amnesty diberikan pemahaman yang baik mengenai tax amnesty melalui sosialisasi maka masyarakat akan tertarik untuk mengikuti program ini disamping keuntungan yang diberikan. Sosialisasi dilakukan untuk memberikan informasi mengenai program tax amnesty secara baik dan benar sehingga wajib pajak memiliki pengetahuan mengenai tax amnesty.

Keikutsertaan wajib pajak dalam program tax amnesty mengindikasikan kepatuhan wajib pajak terhadap peraturan perpajakan. Junpath (2013) menyatakan bahwa kebijakan tax amnesty memiliki pengaruh positif pada kepatuhan wajib pajak orang pribadi. Menurut Brown dan Maznur (2003) dalam Marcori (2018) salah satu bentuk kepatuhan adalah kepatuhan pelaporan (reporting compliance). Dengan mengikuti kebijakan tax amnesty maka wajib pajak telah bersedia melakukan transparansi atas asetnya terhadap Dirjen Pajak yang dapat diartikan sebagai kepatuhan wajib pajak dalam bentuk pelaporan.

Berdasarkan penelitian yang dilakukan oleh Samadiartha \& Sri Darma (2017) ditemukan bahwa sosialisasi perpajakan berpengaruh positif terhadap kepatuhan wajib pajak. Apabila pemerintah dengan gencar mensosialisasikan pajak maka wajib pajak akan patuh terhadap pajak. Hal ini mengindikasikan bahwa apabila tax amnesty dengan gencar disosialisasikan maka semakin tinggi pula wajib pajak yang mau mengikuti program pengampunan pajak. Hasil penelitian ini didukung juga oleh penelitian Ananda, et al. (2015) juga Nopiana \& Natalia (2018) yang menemukan bahwa semakin tinggi tingkat sosialisasi maka akan semakin tinggi pula kepatuhan wajib pajak. Namun masih ada inkonsistensi hasil dimana dalam penelitian Winerungan (2013) ditemukan bahwa sosialisasi perpajakan tidak berpengaruh terhadap kepatuhan wajib pajak. Penelitian ini mengindikasikan bahwa meskipun pemerintah melakukan sosialisasi tax amnesty, wajib pajak tidak akan tertarik mengikuti program tax amnesty. Penelitian ini juga didukung oleh penelitian Herryanto \& Toly (2013) juga Subandi \& Fadhil (2018) yang menemukan hasil yang sama.

Adanya keinkonsistenan hasil penelitian memungkinkan adanya variabel lain yang menjadi variabel moderating atau intervening. Diperlukan upaya untuk merekonsiliasi ketidakkonsistenan dengan cara mengidentifikasi faktor-faktor 
kondisional antara kedua variabel tersebut dengan pendekatan kontijensi (Govindarajan, 1988). Dalam perspektif kontigensi, sebagian besar hubungan antara dua variabel dipengaruhi oleh variabel lain (Boyd et al., 2012). Kontigensi harus dianggap sebagai orientasi stategi yang memberi ruang untuk memasukkan fenomena yang seharusnya dikonseptualisasikan dibanding teori yang sebenarnya (Schoonhoven, 1991). Argumen sentral dari paradigma kontigensi adalah bagaimana suatu tindakan sesuai untuk kontigensi yang mencerminkan situasi yang menentukan efektivitas tindakan (Thai, 2015).

Perilaku manusia dapat didasari oleh adanya dorongan internal dan eksternal. Dalam teori atribusi dijelaskan bahwa adanya dorongan dari luar individu tersebut akan mempengaruhi tindakan yang dilakukan. Sosialisasi perpajakan merupakan salah satu dorongan eksternal yang dapat meningkatkan motivasi wajib pajak dalam mengikuti tax amnesty. Sosialisasi perpajakan juga dapat merupakan perceived behavioral control yang merupakan kontrol perilaku bagi wajib pajak untuk melakukan tindakan terencana berupa mengikuti tax amnesty.

Penyebab tax amnesty belum efektif disebabkan oleh kurang meluasnya sosialisasi (Jamil, 2017). Berdasarkan penelitian Andreas \& Savitri (2015) menemukan bahwa sosialisasi perpajakan berpengaruh positif terhadap kepatuhan wajib pajak yang dibuktikan dengan peningkatan jumlah pendaftaran Nomor Pokok Wajib Pajak (NPWP). Hasil penelitian ini juga diperkuat oleh penelitian Ananda, et al. (2015) yang menemukan bahwa sosialisasi perpajakan berpengaruh positif terhadap kepatuhan. Keikutsertaan wajib pajak dalam program tax amnesty adalah salah satu bentuk kepatuhan wajib pajak terhadap aturan perpajakan. Oleh karena itu, dapat ditarik hipotesis sebagai berikut:

$\mathrm{H}_{1}$ : Sosialisasi Perpajakan berpengaruh terhadap Tax Amnesty.

Teori Atribusi menjelaskan bahwa persepsi mengenai kemudahan prosedur tax amnesty dapat membuat dorongan prilaku secara internal yang dihasilkan oleh pemikiran dari wajib pajak tersebut mengenai kemudahan prosedur tax amnesty. Dengan adanya persepsi bahwa tax amnesty dapat dilakukan dengan prosedur yang mudah maka wajib pajak akan merasa lebih tertarik untuk mengikuti tax amnesty. Sebaliknya apabila wajib pajak merasa bahwa harus melewati prosedur yang sulit untuk melakukan tax amnesty maka wajib pajak akan mempertimbangkan kembali untuk ikut. Dengan adanya persepsi kemudahan ini akan menumbuhkan minat wajib pajak mengikuti tax amnesty. Persepsi kemudahan merupakan implementasi perceived behavioral control atau persepsi kontrol perilaku dalam theory of planned behavior yang dapat mempengaruhi perilaku wajib pajak dalam mengikuti tax amnesty. Perceived behavioral control dapat berpengaruh secara langsung terhadap intensi perilaku seseorang maupun berpengaruh melalui hubungannya dengan variabel lain.

Berdasarkan penelitian Pinatik \& Rais (2015) ditemukan bahwa wajib pajak akan lebih patuh bila terdapat kemudahan dalam sistem perpajakan. Didukung oleh penelitian Chai \& Fan (2016) yang menyatakan bahwa persepsi mengenai kemudahan dapat memotivasi perilaku. Hasil penelitian (Barati \& Bakhshayesh, 2015) menunjukkan bahwa adanya hubungan yang signifikan antara persepsi mengenai kemudahan dan sikap wajib pajak. Dengan adanya 
persepsi mengenai kemudahan prosedur maka wajib pajak akan semakin tertarik mengikuti tax amnesty.

$\mathrm{H}_{2}$ : Kemudahan Prosedur Tax Amnesty Memperkuat Hubungan antara Sosialisasi Perpajakan dengan Tax amnesty.

Dengan adanya persepsi mengenai risiko offshore investment maka akan menciptakan perceived behavioral control yang akan berpengaruh terhadap perilaku dari wajib pajak untuk mengikuti tax amnesty. Dalam theory of planned behavior dijelaskan bahwa perceived behavioral control dapat berpengaruh langsung terhadap intensi perilaku maupun memperkuat pengaruh suatu intensi tindakan lainnya. Wajib pajak bisa saja berpikir bahwa akan jauh lebih menguntungkan secara finansial apabila melakukan offshore investment, namun pemikiran tersebut bisa saja ditolak karena merasa adanya risiko yang akan dihadapi bila melakukan offshore investment. Didukung oleh teori atribusi yang menyatakan bahwa perilaku manusia disebabkan oleh internal dan eksternal, dengan adanya persepsi mengenai risiko offshore investment maka secara internal perilaku wajib pajak tersebut telah terpengaruhi.

Saat menentukan pilihan investasi, orang akan didominasi oleh pertimbangan antara risiko dan tujuan untuk mendapatkan utilitas maksimum (Arianti, 2017). Torgler \& A.García-Valiñas (2007) menyampaikan bahwa keputusan wajib pajak individu dapat dipengaruhi oleh sikap mereka terhadap risiko. Penurunan persepsi mengenai risiko dapat meningkatkan kepercayaan pelanggan (Chang \& Chen, 2008). Kaitannya dengan persepsi mengenai offshore investment adalah apabila wajib pajak memiliki persepsi risiko yang lebih rendah mengenai offshore investment, maka wajib pajak akan lebih memilih menginvestasikan asetnya di luar negeri dibandingkan mengikuti tax amnesty di dalam negeri karena tax amnesty dianggap kurang menguntungkan. Pandangan ini didukung oleh hasil penelitian Marakanon \& Panjakajornsak (2017) yang menemukan bahwa persepsi mengenai risiko berpengaruh terhadap loyalitas pelanggan. Berdasarkan penelitian yang dilakukan Arena \& Zengin (2016) persepsi risiko berpengaruh positif pada preferensi investasi individu.

Berdasarkan pemaparan tersebut maka dapat ditarik hipotesis sebagai berikut:

$\mathrm{H}_{3}$ : Risiko Offshore Investment Memperkuat Hubungan antara Sosialisasi Perpajakan dengan Tax Amnesty.

\section{METODE PENELITIAN}

Penelitian ini dilakukan di Kantor Pelayanan Pajak Pratama Badung Utara yang beralamat di Jalan Ahmad Yani No.100, Denpasar Utara. Kantor Pelayanan Pajak Pratama Badung Utara dipilih karena ditemukan masih banyak wajib pajak yang belum patuh.

Penelitian ini mengambil populasi seluruh wajib pajak yang terdaftar di Kantor Pelayanan Pajak Pratama Badung Utara yang berjumlah 55.627 orang Wajib Pajak. Metode penentuan sampel yang digunakan pada penelitian ini adalah simple convenience sampling. Maka jumlah anggota sampel pada penelitian ini menggunakan convenience sampling dengan jumlah sampel yang digunakan berdasarkan rumus Slovin. Rumus Slovin disajikan sebagai berikut:

$n=\frac{N}{1+N\left(d^{2}\right)}$ 
Keterangan:

$\mathrm{n} \quad=$ Sampel

$\mathrm{N} \quad=$ Populasi

$\mathrm{d} \quad=$ Nilai presisi $90 \%$ atau sig. $=0,1$ berikut.

Perhitungan jumlah sampel dengan rumus Slovin disajikan sebagai

$$
n=\frac{55.627}{1+55.627\left(0,1^{2}\right)}=99,821
$$

Dengan rumus Slovin, maka jumlah sampel yang diambil sejumlah 99,821. Dibulatkan menjadi 100 wajib pajak.

Hipotesis dalam penelitian diuji menggunakan regresi logistic biner. Penelitian ini juga menggunakan variabel moderasi. Variabel moderasi nantinya akan membuktikan apakah akan memperkuat atau memperlemah hubungan antara variabel independent dan dependen. Cara pengujian variabel moderasi dalam penelitian ini menggunakan uji interaksi atau biasa disebut dengan Moderated Regression Analysis (MRA). Model regresi yang digunakan dalam penelitian ini ditunjukkan dalam persamaan sebagai berikut:

$$
\begin{aligned}
& \operatorname{Ln} \frac{T A}{1-T A}=\alpha+\beta_{1} X+\beta_{2} M_{1}+\beta_{3} M_{2}+\varepsilon \\
& \operatorname{Ln} \frac{T A}{1-T A}=\alpha+\beta_{2} X \cdot M_{1}+\beta_{3} X \cdot M_{2}+\varepsilon
\end{aligned}
$$

Keterangan:

$$
\begin{array}{ll}
\operatorname{Ln}_{1-T A}= & \begin{array}{l}
\text { Dummy variable tax amnesty (kategori } 1 \text { untuk melakukan tax amnesty } \\
\text { dan kategori } 0 \text { untuk tidak melakukan tax amnesty) }
\end{array} \\
\alpha \quad= & \text { Koefisien Regresi } \\
\beta_{i} & =\text { Koefisien Regresi, dimana } i=1,2,3 \\
\mathrm{X} & =\text { Sosialisasi Perpajakan } \\
\mathrm{M}_{1} \quad=\text { Kemudahan Prosedur Tax Amnesty } \\
\mathrm{M}_{2} \quad=\text { Risiko Offshore Investment } \\
\varepsilon & =\text { Error }
\end{array}
$$

\section{HASIL DAN PEMBAHASAN}

Berdasarkan hasil olahan SPSS 17 yang meliputi variabel sosialisasi perpajakan, kemudahan prosedur, risiko offshore investment dan tax amnesty didapat hasil analisis data untuk statistik deskriptif yang dapat dilihat pada tabel 3.

\section{Tabel 3. Hasil Statistik Deskriptif}

\begin{tabular}{llllll}
\hline Variabel & $\mathrm{N}$ & Minimum & Maksimum & Mean & $\begin{array}{l}\text { Std. } \\
\text { Deviasi }\end{array}$ \\
\hline Tax Amnesty (Y) & 100 & 0 & 1 & 0.41 & 0.494 \\
Sosialisasi Perpajakan (X1) & 100 & 1,56 & 4,89 & 3.6700 & 0,66244 \\
Kemudahan Prosedur (M $\mathrm{M}_{1)}$ & 100 & 1,00 & 5,00 & 3,2350 & 0,86370 \\
Risiko Offshore Investment & 100 & 2,38 & 4,88 & 3,5963 & 0,54554 \\
$\left(\mathrm{M}_{2}\right.$ & 100 & & & & \\
Valid N (listwise) & & & & & \\
\hline
\end{tabular}

Sumber: Data Penelitian, 2019

Berdasarkan statistik deskriptif yang ditunjukkan pada Tabel 3. digunakan nilai minimum dari besaran keikutsertaan tax amnesty sebesar 0 yang 
berarti tidak mengikuti tax amnesty dan 1 yang berarti mengikuti tax amnesty. Nilai rata-rata dari tax amnesty sebesar 0,41 yang artinya keikutsertaan tax amnesty cenderung lebih sedikit dibandingkan yang tidak mengikuti tax amnesty. Nilai standar deviasi lebih besar dari nilai rata rata, yaitu 0,494 >0,41 yang berarti bahwa berarti bahwa tax amnesty memiliki sebaran yang besar sehingga simpangan data kurang baik. Data yang terlalu ekstrim ini disebabkan karena variabel Y merupakan variabel dummy.

Pada Tabel 3. ditunjukkan bahwa nilai minimum dari variabel sosialisasi perpajakan adalah 1,56 dan nilai tertingginya sebesar 4,89. Nilai rata-rata sosialisasi perpajakan sebesar 3,67 yang artinya sosialisasi perpajakan cenderung tinggi. Standar deviasi sebesar 0,66244 nilai ini menunjukkan bahwa data bervariasi dengan indikasi bahwa data baik dan tidak terjadi bias atau penyimpangan.

Nilai tertinggi variabel kemudahan prosedur menurut tabel 3 adalah sebesar 5 sementara nilai terendahnya adalah 1 . Nilai rata-rata kemudahan prosedur adalah 3,2350 yang artinya variabel kemudahan prosedur cenderung tinggi. Standar deviasi sebesar 0,86370 dimana nilai standar deviasi lebih rendah dibanding rata-rata yang menunjukkan bahwa data bervariasi, baik dan tidak terjadi bias atau penyimpangan.

Berdasarkan Tabel 3. variabel risiko offshore investment memiliki nilai tertinggi sebesar 4,88 dan nilai terendahnya adalah 2,38 . Nilai rata-rata risiko offshore investment sebesar 3,5963 yang artinya sebaran data cenderung tinggi. Standar deviasi sebesar 0,54554 yang menunjukkan bahwa data bervariasi, baik dan tidak terjadi bias atau penyimpangan.

Menilai Kelayakan Model Regresidilakukan untuk menguji hipotesis nol bahwa data empiris cocok atau sesuai dengan model. Kelayakan model refresi dinilai dengan menggunakan uji Hosmer and Lemeshow's Goodness of Fit Test. Jika nilai statistik uji Hosmer and Lemeshow's Goodness of Fit Test lebih besar dari 0,05 maka hipotesis nol diterima dan berarti model mampu memprediksi nilai observasinya atau dapat dikatakan model dapat diterima karena cocok dengan data observasinya. Berikut disajikan tabel uji Hosmer and Lemeshow's Goodness of Fit Test.

Tabel 4. Hasil Uji Kelayakan Model Regresi dengan Hosmer and Lemeshow's Goodness of Fit Test

\begin{tabular}{lllll}
\hline & Step & Chi-Square & Df & Sig. \\
\hline Model 1 & 1 & 6,001 & 8 & 0,647 \\
Model 2 & 1 & 7,971 & 8 & 0,436 \\
\hline
\end{tabular}

Sumber: Data Penelitian, 2019

Pada model 1 uji Hosmer and Lemeshow's Goodness of Fit Test yang disajikan diatas dapat dilihat bahwa nilai signifikansi uji Hosmer and Lemeshow sebesar 0,647. Nilai hasil uji lebih besar dari 0,05 sehingga hipotesis nol diterima yang berartu bahwa model mampu memprediksi nilai observasinya atau dapat dikatakan model dapat diterima karena cocok dengan data observasinya.

Pada tabel uji Hosmer and Lemeshow's Goodness of Fit Test yang disajikan pada model 2 dapat dilihat bahwa nilai signifikansi uji Hosmer and Lemeshow sebesar 0,436 dimana nilai ini lebih besar dari 0,05 sehingga hipotesis nol diterima atau dapat dikatakan bahwa model mampu memprediksi nilai 
observasinya sehingga model dapat diterima. Berdasarkan hasil uji Hosmer and Lemeshow's Goodness of Fit Test pada kedua model, maka dapat disimpulkan bahwa kedua model dapat diterima.

Menilai Keseluruhan Model (Overall Model Fit) dilakukan untuk mengetahui apakah keseluruhan model sesuai dnegan data. Pengujian dilakukan dengan membandingkan nilai antara -2 Log Liklehood (-2LL) pada awal (Block Number $=0)$ dengan nilai -2 Log Liklehood (-2LL) pada akhir $($ Block Number $=1)$. Apabila terdapat penurunan nilai Liklehood, ini menunjukkan model regresi yang baik atau dengan kata lain model yang dihipotesiskan fit dengan data. Hasil pengujian ditampilkan dalam Tabel 5 . berikut:

Tabel 5. Perbandingan -2 Log Liklehood Awal dan Akhir

\begin{tabular}{lll}
\hline \multirow{2}{*}{ Model 1 } & -2LL awal (Block Number $=0$ ) & 135,372 \\
& -2LL akhir (Block Number $=1$ ) & 75,160 \\
Model 2 & -2LL awal (Block Number $=0$ ) & 135,372 \\
& -2LL akhir (Block Number $=1)$ & 76,992 \\
\hline
\end{tabular}

Sumber: Data Penelitian, 2019

Pada model 1, nilai -2LL awal sebesar 135,372 sementara nilai -2LL akhir sebesar 75,160. Nilai -2LL pada awal dan akhir menunjukkan penurunan sehingga berdasarkan data tersebut menunjukkan bahwa model regresi baik.

Pada model 2, nilai -2LL juga mengalami penurunan dari nilai -2LL awal sebesar 135,372 menjadi 76,992 yang menunjukkan bahwa model regresi baik.

Berdasarkan data tersebut maka dapat disimpulkan bahwa baik pada model 1 maupun model 2 keduanya merupakan model regresi yang baik atau merupakan model yang fit dengan data.

Besarnya nilai koefisien determinasi pada model regresi logistik ditunjukkan dnegan nilai Nagelkerke's $R$ Square yaitu variabilitas variabel tetap yang dapat dijelaskan oleh variabel-variabel lain diluar penelitian. Nagelkerke's $R$ Square ini digunakan untuk mengukur seberapa besar variabel bebas yang digunakan dalam penelitian ini yaitu sosialisasi perpajakan mampu mempengaruhi variabel terikat yaitu tax amnesty. Berikut hasil pengujian pada tabel 6 .

Tabel 6. Hasil Uji Nagelkerke's R Square pada Model 1 dan 2

\begin{tabular}{llllll}
\hline & Step & $\begin{array}{l}-2 \\
\text { Likelihood }\end{array}$ & $\begin{array}{l}\text { Log } \\
\text { Square }\end{array}$ & $\begin{array}{l}\text { Cox \& } \\
\text { Squell R }\end{array}$ & Nagelkerke R Square \\
\hline Model 1 & 1 & 75,160 & 0,452 & 0,610 \\
Model 2 & 1 & 76,992 & 0,442 & 0,596 \\
\hline
\end{tabular}

Sumber: Data Penelitian, 2019

Berdasarkan Tabel 6. menunjukkan nilai Nagelkerke's $R$ Square sebesar 0,610 pada model 1 dan 0,602 pada model 2 . Hal ini berarti variabel bebas yaitu sosialisasi perpajakan, serta variabel moderasinya yaitu kemudahan prosedur dan risiko offshore investment yang digunakan dalam penelitian ini mampu menjelaskan variabilitas variabel terikat yaitu tax amnesty sebesar $61 \%$ sedangkan $39 \%$ dijelaskan oleh variabel lain yang tidak dimasukkan dalam penelitian ini pada model 1, sementara pada model 2 variabel bebas dan variabel moderasi dapat menjelaskan variabilitas variabel terikat sebesar 59,6\% sementara 40,4\% dijelaskan oleh variabel lain yang tidak dimasukkan dalam penelitian ini. 
Hasil pengujian menunjukkan kekuatan prediksi dari model regresi 1 dan 2 untuk memprediksikan kemungkinan wajib pajak tidak mengikuti tax amnesty adalah sebesar $84,0 \%$. Hal ini menunjukkan bahwa dengan model regresi tersebut, terdapat 59 orang wajib pajak yang tidak mengikuti tax amnesty dan 41 orang wajib pajak akan mengikuti tax amnesty dari total 100 data wajib pajak sampel selama periode pengamatan.

Berdasarkan hasil analisis dengan menggunakan program SPSS 17 maka diperoleh hasil berikut:

Tabel 7. Hasil Uji Koefisien Regresi pada Model 1

\begin{tabular}{|c|c|c|c|c|c|c|c|c|}
\hline & & & B & S.E. & Wald & Df & Sig. & $\operatorname{Exp}(B)$ \\
\hline \multirow{4}{*}{ Model 1} & Step 1 & $\mathrm{X} 1$ & 0,259 & 0,075 & 11,819 & 1 & 0,001 & 1,296 \\
\hline & & M1 & 0,281 & 0,111 & 6,372 & 1 & 0,012 & 1,325 \\
\hline & & M2 & 0,056 & 0,074 & 0,561 & 1 & 0,454 & 1,057 \\
\hline & & Constant & $-14,452$ & 2,933 & 24,276 & 1 & 0,000 & 0,000 \\
\hline \multirow{3}{*}{ Model 2} & Step 1 & X1M1 & 0,009 & 0,003 & 9,472 & 1 & 0,002 & 1,009 \\
\hline & & X1M2 & 0,003 & 0,002 & 2,949 & 1 & 0,086 & 1,003 \\
\hline & & Constant & $-7,380$ & 1,470 & 25,193 & 1 & 0,000 & 0,001 \\
\hline
\end{tabular}

Sumber: Data Penelitian, 2019

Berdasarkan Tabel 7. diperoleh persamaan regresi sebagai berikut:

$$
\begin{gathered}
\frac{T A}{\operatorname{Ln} 1-T A}=-14,452+0,259 X+0,281 M_{1}+0,056 M_{2}+\varepsilon \\
\frac{T A}{1-T A}=-7,380+0,009 X \cdot M_{1}+0,003 X \cdot M_{2}+\varepsilon
\end{gathered}
$$

Hasil pengujian dengan menggunakan regresi logistik menunjukkan nilai koefisien positif sebesar 0,259 dengan signifikansi 0,001 dimana nilai ini lebih kecil dibandingkan $\alpha=5 \%(0,001<0,005)$. Sehingga dapat diinterpretasikan bahwa variabel sosialisasi perpajakan berpengaruh positif pada tax amnesty. Dengan adanya sosialisasi perpajakan maka wajib pajak akan lebih mengerti mengenai perpajakan khususnya tax amnesty. Wajib pajak yang mengetahui pentingnya tax amnesty dan tata cara mengikuti tax amnesty cenderung akan memilih mengikuti tax amnesty.

Berdasarkan teori Atribusi, sosialisasi perpajakan merupakan faktor eksternal yang mempengaruhi individu dalam melaksanakan tax amnesty. Sosialisasi perpajakan dikatakan semakin baik apabila adanya sosialisasi perpajakan dapat membuat wajib pajak lebih mengerti mengenai pentingnya pajak terutama kebijakan tax amnesty sehingga akan dapat meningkatkan minat wajib pajak untuk melaporkan pajaknya melalui kebijakan tax amnesty.

Berdasarkan theory of planned behavior, sosialisasi perpajakan merupakan tindakan perceived behavioral control atau kontrol perilaku yang dapat membuat seseorang melakukan perilaku terencana. Dengan adanya sosialisasi perpajakan yang efektif dapat membuat wajib pajak mengetahui pentingnya perpajakan terutama tax amnesty, hal ini akan meningkatkan persepsi wajib pajak bahwa tax amnesty adalah perilaku yang baik dilakukan. Dalam theory of planned behavior, perceived behavioral control dapat mempengaruhi intensi perilaku terencana dari wajib pajak secara langsung. Hal ini dibuktikan dengan pengaruh $X$ atau sosialisasi pajak yang secara langsung berpengaruh signifikan terhadap $Y$ yaitu tax amnesty. 
Berdasarkan frekuensi jawaban responden yang diperoleh dari kuisioner pada variabel sosialisasi perpajakan, pernyataan nomor 5 dan 9 yang masingmasing pernyataan menerima skor tertinggi sebesar 391. Hal ini mengindikasikan bahwa sosialisasi paling efektif dan paling banyak diterima masyarakat adalah melalui media elektronik seperti televisi dan website. Pernyataan nomor 5 menerima skor yang tertinggi mengartikan bahwa sosialisasi perpajakan membuat wajib pajak melaksanakan tindakan sesuai ketentuan perpajakan.

Hasil penelitian ini sejalan dengan penelitian Sudrajat dan Ompusunggu (2015), Burhan \& Pratiwi, (2015), juga Dewi Kusuma Wardani \& Erma Wati (2018) yang menemukan hasil bahwa sosialisasi perpajakan berpengaruh terhadap kepatuhan wajib pajak. Partisipasi tax amnesty merupakan bentuk dari kepatuhan perpajakan. Hal ini dibuktikan dengan penelitian Wirawan \& Noviari (2017) dan Hutasoit (2017) membuktikan bahwa tax amnesty berpengaruh terhadap kepatuhan wajib pajak sehingga wajib pajak yang mengikuti tax amnesty dapat dikatakan sebagai wajib pajak yang patuh.

Hasil pengujian menggunakan regresi logistik menunjukkan nilai koefisien positif koefisien sebesar 0,009 dengan tingkat signifikansi sebesar 0,002 pada variabel interaksi antara sosialisasi perpajakan dan kemudahan prosedur terhadap tax amnesty. Nilai signifikansi lebih rendah dari $\alpha=5 \%(0,002<0,005)$ sehingga dapat diinterpretasikan bahwa kemudahan prosedur memperkuat hubungan antara sosialisasi perpajakan terhadap variabel tax amnesty. Dengan adanya prosedur yang dianggap mudah maka wajib pajak akan lebih tertarik untuk mengikuti tax amnesty. Prosedur yang menyulitkan wajib pajak untuk mengikuti tax amnesty akan membuat wajib pajak berpikir dua kali bila ingin mengikuti program tax amnesty.

Berdasarkan penelitian ini kemudahan prosedur secara parsial tidak mempengaruhi tax amnesty terhadap variabel tax amnesty. Meskipun terdapat prosedur yang mudah tanpa dibarengi oleh adanya sosialisasi mengenai tax amnesty maka tidak akan membuat wajib pajak berminat dalam mengikuti tax amnesty. Hasil pengujian koefisien kemudahan prosedur menunjukkan nilai signifikansi yang lebih tinggi dari $\alpha$ yaitu sebesar 0,012 sehingga dapat dikatakan bahwa secara parsial variabel kemudahan prosedur tidak mempengaruhi tax amnesty.

Berdasarkan teori Atribusi, kemudahan prosedur yang diukur dengan persepsi wajib pajak merupakan faktor internal yang mempengaruhi individu dalam melaksanakan tax amnesty. Prosedur dianggap mudah apabila wajib pajak merasa bahwa mereka bisa melakukan tax amnesty karena tax amnesty bukanlah suatu sistem yang rumit. Kemudahan prosedur dapat menjadi pemoderasi yang memperkuat pengaruh sosialisasi perpajakan terhadap perilaku keikutsertaan tax amnesty.

Dalam theory of planned behavior, kemudahan prosedur merupakan perceived behavioral control yang dapat mempengaruhi intensi perilaku terencana dari wajib pajak secara langsung. Dalam theory of planned behavior, perceived behavioral control dapat mempengaruhi intensi perilaku secara langsung. Kemudahan prosedur selain dapat memperkuat hubungan antara sosialisasi 
perpajakan dengan tax amnesty, dapat juga meningkatkan partisipasi tax amnesty secara langsung. Hal ini dibuktikan dengan hasil nilai koefisien positif sebesar 0,281 dengan nilai signifikansi 0,012 dimana nilai signifikansi lebih rendah dibanding nilai $\alpha=5 \%(0,012<0,05)$.

Berdasarkan frekuensi jawaban responden yang diperoleh dari kuisioner pada variabel kemudahan prosedur, pernyataan nomor 1 menerima skor tertinggi sebesar 338. Hal ini mengindikasikan bahwa apabila wajib pajak mengerti tata cara permohonan tax amnesty akan memperkuat hubungan sosialisasi perpajakan terhadap partisipasi tax amnesty. Wajib pajak yang menerima sosialisasi tax amnesty akan cenderung mengikuti program tax amnesty apabila wajib pajak merasa mengerti tata cara permohonan tax amnesty.

Hasil pengujian dengan regresi logistik menunjukkan nilai koefisien positif 0,003 dengan tingkat signifikansi sebesar 0,086 . Tingkat signifikansi pada variabel interaksi antara risiko offshore investment dan sosialisasi perpajakan lebih tinggi dibandingkan nilai $\alpha$ sebesar $0,05(0,086>0,05)$. Berdasarkan hasil pengujian maka dapat dinyatakan bahwa risiko offshore investment tidak mampu memoderasi pengaruh sosialisasi perpajakan terhadap tax amnesty.

Hasil pengujian dengan regresi logistik menunjukkan koefisien positif 0,056 dengan tingkat signifikansi 0,454 dimana hal ini berarti bahwa risiko offshore investment berpengaruh positif tidak signifikan terhadap tax amnesty yang berarti bahwa risiko offshore investment tidak berpengaruh terhadap prilaku partisipasi tax amnesty.

Hasil penelitian menunjukkan pernyataan dengan skor terbanyak adalah pernyataan nomor 5 yang menyatakan bahwa wajib pajak lebih nyaman menyimpan aset di dalam negeri karena tidak perlu mengkonversikan mata uang yang dapat berubah sewaktu-waktu sehingga dapat disimpulkan bahwa wajib pajak merasa merasa adanya risiko perubahan mata uang apabila melakukan investasi luar negeri. Rata-rata hasil pernyataan responden pada variabel risiko offshore investment adalah 3,5963 yang berarti netral namun cenderung setuju sehingga dapat disimpulkan bahwa wajib pajak cenderung merasakan adanya risiko investasi asing namun merasa tidak mempengaruhinya sehingga memilih untuk menerima adanya risiko tersebut.

Dalam teori atribusi disebutkan bahwa manusia bertindak disebabkan oleh faktor eksternal dan internal. Risiko offshore investment merupakan salah satu faktor eksternal yang dapat menyebabkan seseorang melakukan suatu tindakan, namun pengaruh risiko offshore investment tidak signifikan terhadap partisipasi tax amnesty karena responden baik yang mengikuti tax amnesty maupun tidak mengikuti tax amnesty cenderung merasakan adanya risiko tersebut namun menerima risiko tersebut. Kaitan risiko offshore investment terhadap theory of planned behavior adalah bahwa risiko offshore investment merupakan perceived behavioral control atau persepsi yang dapat menjadi kontrol perilaku, namun hal tersebut tidak terbukti dalam penelitian ini karena risiko offshore investment secara langsung berpengaruh positif namun tidak signifikan terhadap partisipasi tax amnesty dan tidak dapat memoderasi sosialisasi perpajakan terhadap tax amnesty. 
Hasil penelitian menunjukkan bahwa masyarakat cenderung merasakan adanya risiko offshore investment namun tidak mengikuti tax amnesty. Hal ini dapat terjadi karena wajib pajak ingin menghindari penyesalan atau karena wajib pajak telah melaporkan seluruh asetnya atau dapat dikatakan bahwa wajib pajak telah patuh. Dalam regret theory dijelaskan bahwa terjadi reaksi pengalaman emosional setelah seseorang menyadari telah membuat kesalahan penilaian dalam investasinya (Bell, 1982). Berdasarkan penelitian Bailey \& Kinerson (2005), penyesalan dan pengambilan risiko mempengaruhi keputusan individu untuk berinvestasi. Agar seorang wajib pajak tidak merasakan penyesalan dengan melakukan offshore investment yang berisiko, maka wajib pajak cenderung patuh dan tidak mengalihkan asetnya ke luar negeri sehingga wajib pajak cenderung merasakan bahwa ada risiko yang tinggi ketika melakukan offshore investment namun merasakan bahwa risiko tersebut tidak mempengaruhinya atau dapat dikatakan bahwa wajib pajak cenderung merasa netral akan risiko offshore investment. Melaporkan pajak dengan baik dan melakukan hal konfensional yang tidak menyimpang dari norma akan membuat orang merasa lebih baik. Orang akan merasa lebih menyesal dan bertanggungjawab atas tindakannya yang menyimpang dari norma karena orang-orang lebih mudah membayangkan melakukan hal yang konfensional atau biasa dilakukan (Kahenman \& Miller, 1986).

\section{SIMPULAN}

Semakin tinggi sosialisasi perpajakan, maka akan semakin tinggi partisipasi tax amnesty. Hal ini dibuktikan dengan nilai koefisien positif pada sosialisasi perpajakan sebesar 0,259 dengan signifikansi 0,001 yang lebih rendah dari $\alpha$ $(0,001<0,05)$.

Kemudahan prosedur dapat meningkatkan partisipasi tax amnesty. Hal ini dibuktikan dengan nilai koefisien positif pada kemudahan prosedur sebesar 0,281 dengan signifikansi sebesar 0,012 yang lebih rendah dari $\alpha(0,012<0,05)$.

Risiko offshore investment tidak berpengaruh terhadap partisipasi tax amnesty. Hal ini dibuktikan dengan nilai koefisien positif pada risiko offshore investment sebesar 0,056 dengan signifikansi sebesar 0,454 yang lebih tinggi dari $\alpha(0,454>0,05)$.

Sosialisasi perpajakan akan semakin meningkatkan partisipasi tax amnesty jika didukung dengan kemudahan prosedur. Hal ini dibuktikan dengan kemampuan kemudahan prosedur memoderasi positif hubungan antara sosialisasi perpajakan dengan tax amnesty dimana nilai koefisien pada interaksi antara kemudahan prosedur dengan sosialisasi perpajakan sebesar 0,009 dengan tingkat signifikansi yang lebih rendah dari ${ }^{\alpha}$ yaitu $0,002(0,002<0,05)$.

Risiko offshore investment tidak terbukti meningkatkan pengaruh sosialisasi perpajakan terhadap partisipasi tax amnesty. Hal ini dibuktikan dengan ketidakmampuan risiko offshore investment memoderasi pengaruh sosialisasi perpajakan terhadap tax amnesty dimana nilai koefisien pada interaksi risiko offshore investment dengan sosialisasi perpajakan sebesar 0,003 dengan tingkat signifikansi yang lebih tinggi dari $\alpha$ yaitu sebesar $0,086(0,085>0,05)$. 


\section{REFERENSI}

Akbar Barati; Shahriar Bakhshayesh. (2015). Electronic Tax System And The Facing Challanges (Case Study: Kermanshah Province Tax Payers). Indian Journal of Fundamental and Applied Life Sciences ISSN:2231-6345, 5, 480-497.

Ananda, P. R. D., Kumadji, S., \& Husaini, A. (2015). Pengaruh Sosialisasi Perpajakan, Tarif Pajak, Dan Pemahaman Perpajakan Terhadap Kepatuhan Wajib Pajak (Studi Kasus pada UMKM yang Terdaftar sebagai Wajib Pajak di Kantor Pelayanan Pajak Pratama Batu). Jurnal Perpajakan (JEJAK) |, 6(2), 1-9.

Andreas, \& Savitri, E. (2015). The Effect of Tax Socialization, Tax Knowledge, Expediency of Tax ID Number and Service Quality on Taxpayers Compliance with Taxpayers Awareness as Mediating Variables. Procedia - Social and Behavioral Sciences, 211(September), 163-169. https://doi.org/10.1016/j.sbspro.2015.11.024

Arena, S., \& Zengin, A. N. (2016). Influence of Financial Literacy and Risk Perception on Choice of Investment. 12th International Strategic Management Conference, ISMC 2016.

Arianti, B. F. (2017). The Influence of Financial Literacy, Financial Behavior and Income on Investment Decision. European Research Studies Journal, 20(3A), 635-648.

Bailey, J. J., \& Kinerson, C. (2005). Regret avoidance and risk tolerance. Journal of Financial Counseling and Planning, 16(1), 23-28.

Balipost. (2019, March 18). Cuma Segini, Persentase Kontribusi WP OP di Bali.

Bell, D. E. (1982). Regret in Decision Making Under Uncertainty. Operation Research, 30, 961-981.

Boyd, B. K., Haynes, K. T., \& Hitt, M. A. (2012). Contingency Hypotheses in Strategic Management Research: Use, Disuse, or Misuse? Journal of Management, 38(1).

Burhan, \& Pratiwi, H. (2015). Pengaruh Sosialisasi PErpajakan, Persepsi Wajib Pajak Tentang Sanksi Terhadap Kepatuhan Wajib Pajak ORang Pribadi ( Studi Empiris pada Wajib Pajak di Kabupaten Banjarnegara ). Skripsi FE Undip, 65.

Chai, J. X., \& Fan, K. K. (2016). Mobile Inverted Constructivism: Education of interaction technology in social media. Eurasia Journal of Mathematics, Science and Technology Education, 12(5), 1425-1442. https://doi.org/10.12973/eurasia.2016.1522a

Chang, H.-H., \& Chen, S. W. (2008). The impact of online store environment cues on purchase intention: Trust and perceived risk as a mediator. Online Information Review, 32(6)(818-841).

Devano, S., \& Rahayu, S. (2006). Perpajakan: Konsep, Teori dan Isu. Jakarta: Prenada Media Grup.

Govindarajan, V. (1988). A Contingency Approach to Strategy Implementation at the Business-Unit Level: Integrating Administrative Mechanisms with Strategy. Academy of Management Journal, 31(4).

Herryanto, M., \& Toly, A. A. (2013). Pengaruh kesadaran wajib pajak, kegiatan sosialisasi perpajakan, dan pemeriksaan pajak terhadap penerimaan 
pajak penghasilan di KPP Pratama Surabaya Sawahan. Tax and Accounting Review, 1(1), 125-133.

Hutasoit, G. (2017). Pengaruh Tax Amnesty Terhadap Kepatuhan Wajib Pajak Di Kota Palembang. Seminar Nasional Teknologi Informasi, Bisnis, Dan Desain 2017, 2(978-602-74634-1-7), 43-48.

Jamil, N. A. (2017). Efektivitas Penerapan Tax Amnesty di Indonesia. Academica: Journal of Multidisciplinary Studies, 1(1), 2579-9711.

Jannah, S. Z., \& Basuki, R. (2016). Pengaruh Pengetahuan, Penghasilan, Manfaat Atas NPWP, Sanksi, dan Sosialisasi Terhadap Kepatuhan Pemilik UMKM dalam Memiliki NPWP (Studi Di KPP Pratama Surakarta). Doctoral Dissertation, IAIN Surakarta.

Junpath, S. V. (2013). Multiple tax amnesties and compliance in South Africa. Theses and Disertation Degree of Master of Technology: Taxation, Durban University of Technology.

Kahenman, D., \& Miller, D. T. (1986). Norm theory: Comparing Reality to Its Alternatives. Psychological Review, 93, 136-153.

Kemenkeu.go.id. (2019). Mengenal Rasio Pajak Indonesia. Retrieved February 25, 2019, from kemenkeu.go.id website: https://www.kemenkeu.go.id/publikasi/berita/mengenal-rasiopajak-indonesia/

Kontan.co.id. (2018, December 12). DDTC perkirakan penerimaan pajak tahun ini maksimal hanya 92,9\% dari target. Kontan.Co.Id.

Kumalasari, K. I., Wardany, A. R., \& Kumalsari, S. (2017). Menuju Berakhirnya Program Tax Amnesty. Jurnal Penelitian Trori Dan Terapan Akuntansi, 8(14), 002. https:/ / doi.org/10.32550/teknodik.v8i14.532

Marakanon, L., \& Panjakajornsak, V. (2017). Perceived quality, perceived risk and customer trust affecting customer loyalty of environmentally friendly electronics products. Kasetsart Journal of Social Sciences, 38(1), 24-30. https:// doi.org/10.1016/j.kjss.2016.08.012

Marcori, F. (2018). Pengaruh Kesadaran Wajib Pajak, Pelayanan Fiskus, dan Sanksi Pajak Terhadap Kepatuhan Wajib Pajak Orang Pribadi yang Melakukan Usaha Kecil Menengah (Studi Empiris pada Kantor Pelayanan Penyuluhan dan Konsultasi Perpajakan Kota Sungai Penuh). Skripsi Fakultas Ekonomi Universitas Negeri Padang.

Nopiana, P. R., \& Natalia, E. Y. (2018). Analisis Sosialisasi Pajak Dan Pemanfaatan Teknologi Informasi Terhadap Kepatuhan Pelaporan Spt Wajib Pajak Di Kepulauan Riau. Jurnal Benefita, 3(2), 277. https://doi.org/10.22216/jbe.v3i2.3498

Pinatik, S., \& Rais, M. M. (2015). Pengaruh Manfaat Dan Kemudahan E-Spt Terhadap Pelaporan E-Spt Oleh Wajib Pajak Pribadi Pada Kpp Pratama Bitung. Jurnal Riset Ekonomi, Manajemen, Bisnis Dan Akuntansi, 3(1), 542-552.

Putra, A. H. P. K., Nasir, M., \& Buana, A. P. (2018). Mengungkap Keberhasilan Tax Amnesty: Studi Kasus pada KPP Pajak Pratama Makassar Utara. $\begin{array}{llll}\text { Jurnal Akuntansi Dan Pajak, } & \text { 19(1), }\end{array}$ https://doi.org/10.29040/jap.v19i1.207 
Rahayu, N. (2016). Pengaruh Tax Amnesty Dan Sanksi Pajak Terhadap Kepatuhan Pajak. Equilibrium, 4(2), 15-30.

Samadiartha, K. I., \& Sri Darma, G. (2017). Dampak Sistem E-Filing, Pengetahuan Perpajakan, Sosialisasi Perpajakan, Kesadaran Wajib Pajak terhadap Kepatuhan Wajib Pajak. Jurnal Manajemen Dan Bisnis, 14(1).

Schoonhoven, C. B. (1991). Problems with Contingency Theory: Testing Assumptions Hidden within the Language of Contingency "Theory." Administrative Science Quarterly, 26(3).

Subandi, H., \& Fadhil, M. I. I. (2018). Analisis Faktor-Faktor Yang Mempengaruhi Kepatuhan Pajak Bendahara Desa Di Kota Batu. Berkala Akuntansi Dan Keuangan Indonesia, 3(1), 1. https:/ / doi.org/10.20473/baki.v3i1.5402

Sudrajat, A., \& Ompusunggu, A. P. (2015). Pemanfaatan teknologi Informasi , Sosialisasi Pajak, Pengetahuan Perpajakan, dan Kepatuhan Pajak. Jurnal Riset Akuntansi Dan Perpajakan JRAP Universitas Pancasila, 2(2), 193-202.Tempo.co. (2017). Beberapa Penyebab Target Tax Amnesty Tak Tercapai. Bisnis.Tempo.Co.

Thai, M. (2015). Contingency Perspective. Wiley Encyclopedia of Management, (November 2014), 1-5. https://doi.org/10.1002/9781118785317.weom060036

Torgler, B., \& A.García-Valiñas, M. (2007). The determinants of individuals' attitudes towards preventing environmental damage. Ecological Economics, 63(2-3).

Wardani, K. D., \& Wati, E. (2018). Pengaruh Sosialisasi Perpajakan Terhadap Kepatuhan Wajib Pajak Dengan Pengetahuan Perpajakan sebagai Variabel Intervening (Studi Pada Wajib Pajak Orang Pribadi di KPP Pratama Kebumen). Jurnal Nominal, VII(1).

Winerungan, L. . (2013). Pengaruh Pemanfaatan Aplikasi E-SPT Masa PPN Terhadap Tingkat Kepatuhan Wajib Pajak (Studi Pada Kantor Pelayanan Pajak (KPP) Pratama Surabaya Genteng). Jurnal EPerpajakan, Volume 1(No. 1), 960-970. https:/ / doi.org/ISSN 2303-1174

Wirawan, I. B. N. A. P., \& Noviari, N. (2017). Pengaruh Penerapan Kebijakan Tax Amnesty dan Sanksi Perpajakan Terhadap Kepatuhan Wajib Pajak Orang Pribadi Fakultas Ekonomi dan Bisnis Universitas Udayana ( Unud ), Bali , Indonesia Fakultas Ekonomi dan Bisnis Unive. E-Jurnal Akuntansi Universitas Udayana, 21(3), 2165-2194. https://doi.org/https://doi.org/10.24843/EJA.2017.v21.i03.p17 